\title{
むらの研究に必要な工業数学とその応用" (2)
}

会員川端季雄粎

\section{一目次 -}

1.はじめに

2. 低次要素の伝達特性計算

(1) 0 次比例要素

（2） 1 次比例要素（1 次比例要素の特性，機械系 モデルエアマイクロの動特性など）

(3) 1 次微分要素

\section{3. 変 動の測 度}

(1) 離散的データの場合

（2）連続的データの場合（CV\%，U\%など）

(3) $C V \%$ と $U \%$ 関係について

(4) $U \%, C V \%$ 計算と, そのための電子回路 について

4. 不規則な連続的変動からの情報抽出

(1) 定常確率過程

(2) 自己相関関数

(3) 自己相関関数の計算法

(4) スペクトル密度関数

\section{3. 変 動 の 測 度}

測定したデータが不規則に変動するとき，その変動の 度合を定量化することは重要である。以下に特いてはこ らした問題を中心にしてデータの処理法について説明す る。

（1）離散的データの場合

繰返し的動作によって得た $N$ 個のデータ $x_{1}, x_{2} \cdots \cdots$ $x_{i} ， \cdots \cdots x_{N}$ のそれぞれの值がばらついているとき，こ れらの平均值

$$
\begin{aligned}
\bar{x} & =\frac{1}{N} \sum_{i=1}^{N} x_{i} \\
& =\frac{1}{N}\left(x_{1}+x_{2}+\cdots \cdots+x_{i}+\cdots \cdots+x_{N}\right)
\end{aligned}
$$

はこれらデータの中心的な值を゙示すものである。したが

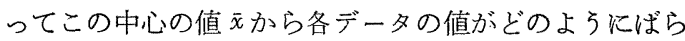
ついているを示すのに $\bar{x}$ のまわりの各データの 2 次モ

$$
\begin{aligned}
& \text { ーメントの平均, すなわち } \\
& \begin{aligned}
\sigma^{2}= & \frac{1}{N} \sum_{i=1}^{N}\left(x_{i}-\bar{x}\right)^{2} \\
= & \frac{1}{N}\left\{\left(x_{1}-\bar{x}\right)^{2}+\left(x_{2}-\bar{x}\right)^{2}+\cdots \cdots+\left(x_{i}-\bar{x}\right)^{2}\right. \\
& \left.\quad+\cdots \cdots+\left(x_{N}-\bar{x}\right)^{2}\right\} \quad \cdots \cdots \cdots \cdots \cdots \cdots \cdots \cdots \cdots \cdots \cdots \cdots(35)
\end{aligned}
\end{aligned}
$$

が一般に使用される。そして $\sigma^{2}$ を分散（variance）と 称しているが，この分散は平均值 $\bar{x}$ からの偏差 $\left(x_{i}-\bar{x}\right)$ が 2 乗されているので中心から離れた值をもつデータほ ぞ分散の值に大きく影暜するわけで，ばらつきの測度と して代表的な存在になっている。またデータの単位とば らつきの測度の単位を揃えるために $\sigma^{2}$ の平方根 $\sigma$ を標 準偏差 (standard deviation) と称して同じく変動の測 度に用いられる。

ところで，いま 2 組の異なったデータの集りを考党， $\mathrm{A}$ 組は平均值 $\bar{x}_{A}$, 標準偏差 $\sigma$ であったとし, 他のB組 は平均値 $\bar{x}_{B}$ で標準偏差は $\mathrm{A}$ 組と等しく $\sigma$ であったと しょ5.しかし $\bar{x}_{A}$ と $\bar{x}_{B}$ が異なる值をとる場合はたと

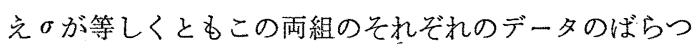
きの大きさは異なるとすべきことが直観されると思う。 たとえば糸の強力を測定しAの糸は $\bar{x}_{A}=10 \mathrm{~g}, \sigma=5 \mathrm{~g}$, $\mathrm{B}$ 糸は $\bar{x}_{B}=100 \mathrm{~g}, \sigma=5 \mathrm{~g}$ であるとすれば強力の均 斉度はたしかにBの糸が優っている。このように平均值 の異なる 2 組の, あるいはそれ以上の各組のばらつきの

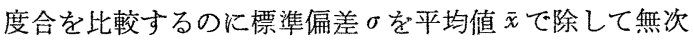
元化する方法がとられている。すなわら

$$
\text { 変動係数 } \quad(C V)=\frac{\sigma}{\bar{x}} \times 100(\%)
$$

が定義されている．たとえば上述の糸の例ではAの系は

$$
\begin{aligned}
C V_{A} & =\frac{5 \mathrm{~g}}{10 \mathrm{~g}} \times 100 \\
& =50 \%
\end{aligned}
$$

Bの杀については

$$
C V_{B}=\frac{5 \mathrm{~g}}{1 \mathrm{COg}} \times 100
$$

* Industrial Mathematics and Its Use in Evaluating Irregularity of Texiles. (2)

** T. Kawabata, Member. 京都大学工学部 


$$
=5 \%
$$

となり，Bの糸の均斉度が高いことを明示できる。

つぎに変動の測度のいま一つの表示法として平均偏差 をとる方法がある，すなわち平均值からの各データ值の 偏差の絶対值和をとる方法である。すなわち

$$
\text { 平均偏差 }=\frac{1}{N} \sum_{i=1}^{N}\left|x_{i}-\bar{x}\right|
$$

この表示は，ばらつきの度合の表示としてたしかに直 観的に理解しやすい測度であり，計算も楽なようであ る.しかし統計学的な見地からするとささの $\sigma$ に比較し て有用の度合は低く特別の場合を除いてあまり用いられ ないが，系むらの場合にはつぎにのべるU\%として広く 用いられている。すなわ台 $\sigma$ に対する $C V$ の意味と同様 の意味で

$$
\text { 平均偏差率 }=\frac{\text { 平均偏差 }}{\bar{x}} \times 100 \%
$$

が用いられて挌り，次項でのべるU\%がそれである。

（2）連続的データの場合

連続的に測定できる系むら測定機の記録曲線のように データが連続的な曲線で得られる場合の曲線の变動の測 度も前項（1）の場合と同じ考方方で求めることができ る.

い屯第 12 図に示したように変動曲線 $f(x)$ が

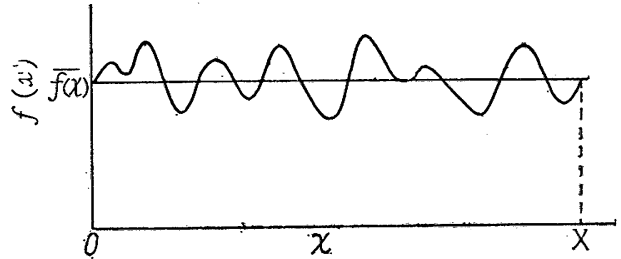

（第12 図） 変 動 曲 線 $f(x)$

与えられたとき，区間 $0 \sim X$ 間の平均值 $\overline{f(x)}$ は

$$
\overline{f(x)}=\frac{1}{X} \int_{0}^{X} f(x) d x
$$

となりこれは（1）項の（34）式に対応する。

また分散 $\sigma^{2}$ は

$$
\sigma^{2}=\frac{1}{X} \int_{0}^{X}(f(x)-\overline{f(x)})^{2} d x
$$

となり（35）式に対応する。したがって

$$
C V=\frac{\sigma}{f(x)} \cdot 100 \%
$$

となる。

同様にして平均偏差も（37）式に対応して

$$
\text { 平均偏差 }=\frac{1}{X} \int_{0}^{X}|f(x)-\overline{f(x)}| d x
$$

とかわり，ここで（42）式の積分は第 13 図の 斜線の面

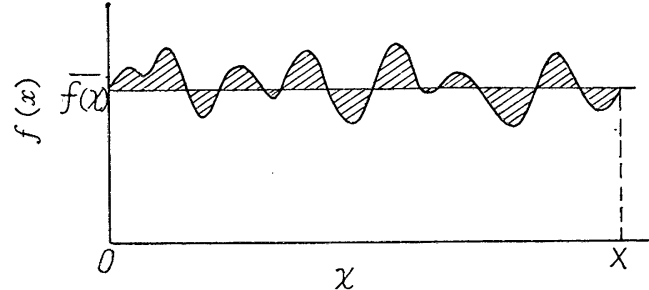

（第13 図） 平均值 $\overline{f(x)}$ 加らの偏差

積になりまた平均偏差率は系むらの場合，U（\%）と 称せられて用いられていることはすでによく知られてい ると和りである。

$$
U(\%)=\frac{\text { 平均偏盖 }}{\overline{f(x)}} \cdot 100 \%
$$

(3) $C V(\%)$ とU(\%) の関係について

以上のべてきたように $C V(\%)$ は標準偏差 $\sigma$ から， またU\%は平均偏差からそれぞれ求めるのであるが両者 の違いは 2 次モーメントと 1 次モーメントとの違いであ るからデータのばらつきの分布が不明であると（この場 合が多い）両者の間にはなんら関係がなく一方から他方 を導くことはできないすなおち本来両者はまったく別 物なのである。しかし分布の形がはじめからわかってい るものとすれば両者の間にある一定の対応がつき，一方 を知って他方を推定することができるようになる。

いま $f(x)=y$ として, $y$ が平均值 $\overline{f(x)}=\bar{y}$ のまわ りに標準偏差 $\sigma$ の正規分布をすると仮定しょう。すなお ち分们関数

$$
P(y)=\frac{1}{\sigma \sqrt{2 \pi}} e^{-\frac{1}{2}\left(\frac{y-\bar{y}}{\sigma}\right)^{2}}
$$

で表わされるとする。すなわら $P(y)$ は正規分布の確率 密度を与光る。いまこの分布にしたがう変動の $U(\%)$ を計算すると（42）（43）式にしたがい

$$
U(\%)=\frac{1}{y} \overline{|y-\bar{y}|} \cdot 100
$$

であるから $P(y)$ を用いてつぎのように誘導できる。

$$
\begin{aligned}
& U(\%)=\frac{-2}{\bar{y}} \int_{-\infty}^{\bar{y}}(y-\bar{y}) \cdot P(y) d y \cdot 100 \\
& \quad=\frac{-2}{\bar{y}} \int_{-\infty}^{\bar{y}}(y-\bar{y}) \frac{1}{\sigma \sqrt{2 \pi}} e^{-\frac{1}{2}\left(\frac{y-\bar{y}}{\sigma}\right)^{2}} d y \cdot 100
\end{aligned}
$$

を計算すればよい. $\{(y-\bar{y}) / \sigma\}^{2}=Z$ とすると（45）式 は

$$
d Z=2 \frac{y-\bar{y}}{\sigma^{2}} d y
$$

として 


$$
\begin{aligned}
U(\%) & =\frac{-2}{\bar{y}} \int_{+\infty}^{0} \frac{\sigma}{2 \sqrt{2 \pi}} e^{-\frac{1}{2} Z} d Z \cdot 100 \\
& =\frac{2 \sigma}{\bar{y} \sqrt{2 \pi}}\left[e^{-\frac{1}{2} Z}\right]_{+\infty}^{0} \cdot 100 \\
& \fallingdotseq \frac{0.797886 \sigma}{\bar{y}} \cdot 100 \ldots \ldots \ldots \ldots \ldots \ldots \ldots \ldots \ldots \ldots
\end{aligned}
$$

一方, $C V(\%)=(\sigma / \bar{y}) \cdot 100$ であるからこれとの比 をとると

$$
\frac{C V(\%)}{U(\%)} \fallingdotseq \frac{(\sigma / \bar{y}) \cdot 100}{(0.79788 \sigma / \bar{y}) \cdot 100}
$$$$
\fallingdotseq 1.25331
$$

が得られる。すなわち $U(\%)$ を約 1.25 倍すれば $C V$ （\%)が得られることになる。もちろんデータの分布が 正規分布にしたがわない場合は（47) 式の関係が成立し ないことは当然である。すし近似的に正規分布にしたが うならば（47）式の関係も近似的にしか成立しない.

(4) $U(\%), C V(\%)$ の計算とそのための電子回 路について

得られたデータがはじめから離散的であるならば(1) の方法によればよい。しかし連続的な曲線として得られ ている場合は，まず第1の方法として第14図に示した ように曲線から離散的にデータを読み取り，（1）の方 法にもらこさ方法がある。

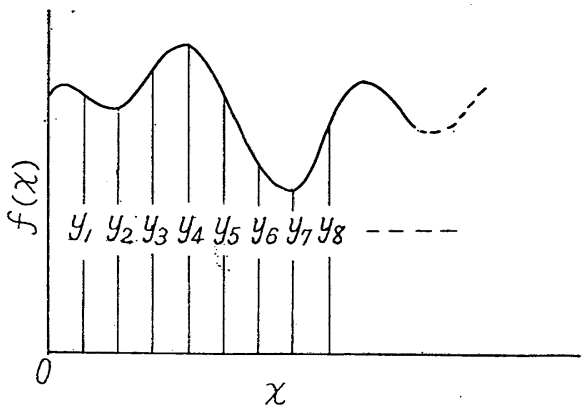

（第14図）サンプリング

この方法で読みの間隔 $\Delta x$ をでさるだけ小さくとるの がもらろん望亡しいが，計算手数が激增するので困るこ とになる。厳密にいうとその曲線が含んでいる最短波長 成分の $1 / 2$ 波長を $\Delta x$ にとればよいのであるが，最短波 長を知るためにはさらに複雑な計算が要求され, 結局自 己矛盾に陌ることになる。そこで，ほぼすべての波をと らえうる程度に細かくということになろう。もらろん 1 次のモーメントを求める平坽偏差の場合は第 11 図の斜 線の面積をプラニメータ，あるいは他の適当な方法で計 量するという途がある。
しかし実際には高速計測のためにも電子回路を利用し て計算するのが適当なように思われる２章でのべた伀 達回路の計算結果を応用しながら簡単に計算原理を説明 してみよ5.

まず比較的簡単な $U \%$ の計算からのべる。

(42)，(43）式からおかるよ5にまず

$$
\frac{1}{X} \int_{0}^{X}|f(x)-\overline{f(x)}| d x
$$

を求めなくてはならない。しかし市販の測定機をみると この（48）式の計算は式のと和りに厳密に行なわれてい ないようで，たとえばアナログコンピュータで演算す るような，積分とその平均值演算操作は行なっていな い。どのような方法であるかを゙つぎに解析してみると， まず計算にあたってつぎの仮定を設ける必要がある。そ の第 1 は糸むらがある特定の波長以上の大きなむらを含 んでいないこと，第2 はむらが定常不規則（さらの性格 が変動しないこと）な性質を有する゙という仮定である。 このような仮定に合うむら曲線 $f(t)$ がいま与えられた としょう。ここで変数に時間 $t$ をっているのは測定機 からのむらの検出値が時間的変動として与えられるから で測定糸速をひとすると糸長 $x$ に対して

$$
x=v t
$$

の関係が成立することは明らかである。

さて, $f(t)$ は時刻 $t$ に预いて検出点を通過する糸の 断面太さを表わするのとすると，なず

$$
f(t)-\overline{f(t)}
$$

を求めなければならない。ここで仮定から $f(t)$ は角周 波数 $\omega_{0}$ 以下の低周波成分を含んでいないと考学ると $f(t)$ はつぎのように表わせる。

$$
f(t)=\overline{f(t)}+\left\{\omega_{0} \text { 以上の角周波数のむら成分 }\right\}
$$

このような信号 $f(t)$ をたとえば第 2 章の（ 3 ）での ベた 1 次微分要素に通し，かつその要素の時定数 $T$ を $\omega_{0}$ 以上の波が減衰しないよ5に選んで叔くとその出力 は $\omega_{0}$ 以上の角周波数のむら成分のみになり，（51）式 から

$$
f(t)-\overline{f(t)}
$$

が得られる。この関係を第 15 図に示した。

つぎにこの出力 $f(t)-\overline{f(t)}$ を゙全波整流する。すなお ち第 16 図のごとく負側の波も正側に反転させるわけで ある.すなわち $|f(t)-\overline{f(t)}|$ を作る。

この全波整流波をつぎに第 2 章（2）でのべた 1 次比 例要素に入れるのであるが，この場合の時定数も第 13 図の回路の時定数と同程度あるい:それ以上に選んでお 


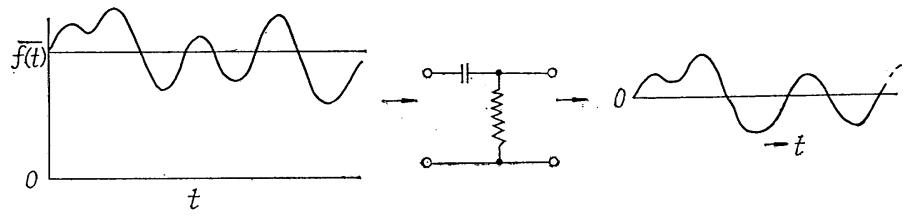

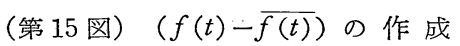

説明の要がないと思う，後者の場合に は第19図のように 3 角波のパルス列 を作りその高さを入力信号 $x$ で变調す ると出力信号の 3 角波群の面積 $y$ は

$$
y=k x^{2}
$$

$k$ : 比例定数
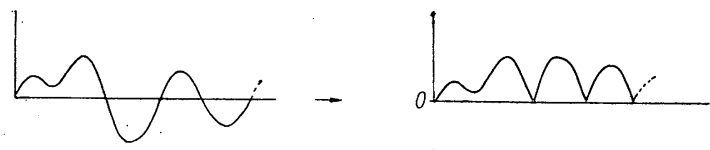

（第16 図） $|f(t)-\overline{f(t)}|$ の作 成

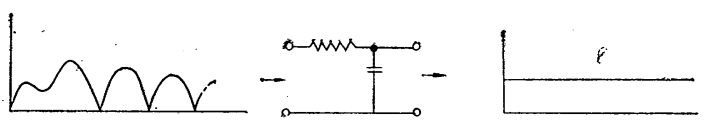

（第17図） $\overline{|f(t)-\overline{f(t)}|}$ の作成

くと,すでに説明したようにこの場合は微分要素と逆に $\omega_{0}$ 成分以上の高い周波数成分を゙減衰させてしまうので 整流波は平均化される。（第17 図）

こうして平均偏差が算出されたのであるが，この值を その采の平均太さで除して 100 倍すれば $U(\%)$ が得ら れる。現状では平均太さの算出とその除算はそれほど正 確に行なわれていないようで半自動的操作によってい る.

つぎに $C V(\%)$ の計算は定義からわかるように偏差 の 2 乗を計算しなければならない。電子回路でこの 2 乗 計算装置を設けた測定機は実用的に使用されているのか どうか不明である注ど，U％が広く採用されているよ ろである。これは 2 乗計算の電子回路が $U(\%)$ 計算回 路に比較すればかなり複雑になるからでああろう。しか 乙2 乗計算回路はさして困難なものではない。その回路 にも多くの種類があるが，大別すると 3 極管などの $E g$ 一IP 特性の曲りを利用したり, あるいはダイオードを 組合せて 2 次曲線的特性を持たせたりする非線形回路を 設ける方法と，パルスの波高を入力信号で変調する方法 がある。前者の一例を第 18 図に示したが，この場合は
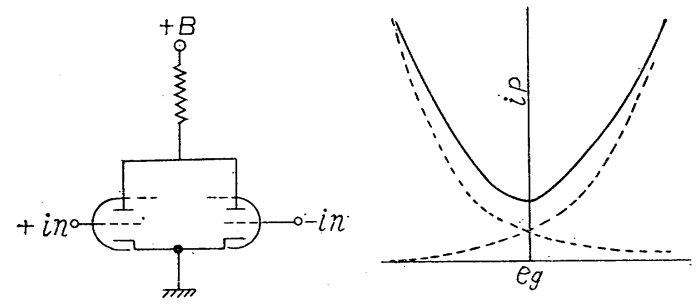

（第 18 図） 真空管の $E q-I p$ 特性を利用した 2 乗計算

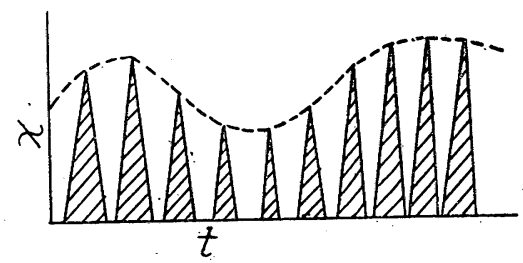

（第19困） 3 角パルスを利用した 2 乗計算

となって 2 乗演算が行なわれる。前者の方法はもちろん として後者の方法も機械的な 2 乗演算法に比較すればは るかに高速度の演算が可能である。

以上計算方法を説明してきたが，たとえば一般に採用 されている $U(\%)$ の計算に和いて前述した $2 つ の$ 仮定 に注意してほしいと思う。もちろんこの仮定が成立しな くとも $U(\%)$ らしい測定值が得られるが，その值の評 価というか解稂はかなりむつかしい問題になる。しかし すでに説明してきたような伝達特性の理解とつぎにのべ るむらの性格に関する知識によってこの問題もさして困 難なるのではなくなるであろう。

\section{4. 不規則な連続的変動からの情報抽出}

前章に括いては，たとえばデータ $x_{1}, x_{2}, \cdots \cdots, x_{i}$, $\cdots \cdots . . x_{N}$ の変動の測度として分散や平均偏差を計算し たが，その計算過程においてデータのならび順序は別に ぞうでるよかった。しかしこれらのデータのならぶ順序 にまで考察を展開しなければならない場合が実は非常に 多い。

たとえば，ある連続工程によって生産される製品の品 質変動はなにに原因するのであろらかという疑問に対し ては時間的な変動状態をくわしく調べる必要がある。さ らにこうした変動がその製品を用いた 2 次製品にどのよ うに影響するかという問題を考劣る際にもまたこの調査 の必要が生じてくるであろう.むらを自動制御の対象と して考觉る際はな持さらである。

\section{（1）定常確率過程}

第 20 図に示したような不規則な波において，たとえ ば $t=t_{0}$ に乱ける值 $f\left(t_{0}\right)$ が $t$ に無関係なある一定の 


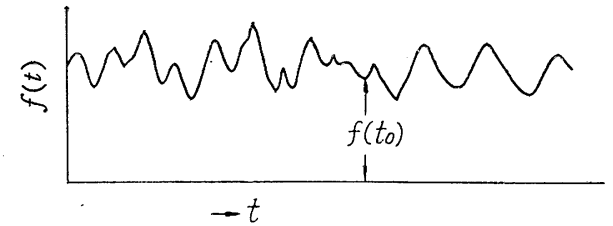

（第 20 図）不 規 則 波

確率的な性質にしたがって生起すると考えられるとき， この確率過程は定常であるという。そしてこのような変 動を定常不規則というように表現する。またこのような 定常確率過程からの，たとえば等間隔サンプリングによ る標本 $f\left(t_{1}\right), f\left(t_{2}\right), f\left(t_{3}\right), \cdots \cdots$ 惊定常時系列である.

(2) 自己相関関数

さて，まずこの定常時系列を例にとってみよう，いま 簡単のため定常時系列 $f_{1}, f_{2}, \cdots \cdots, f_{i}, \cdots \cdots f_{N}$ はと平 均值 $\bar{f}=0$ とする.すなわら $f_{i}$ の基線を $\bar{f}$ にとるわけ である、そして第 21 図のようにプロットすると図のよ

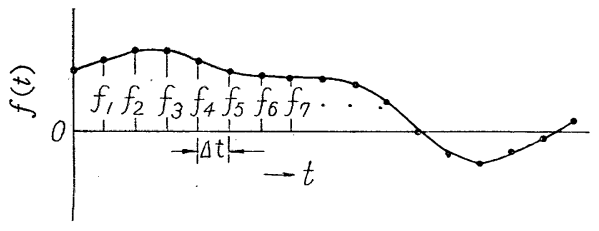

（第 21 図）自己相関関数の算出

らに比較的なめらかな曲線上にならんだ場合を考える。 この事実はたとえば $f_{5}$ と $f_{4}$ ，または $f_{5}$ と $f_{6}$ の間の 相関が比較的高いことを意味していると考えてよいであ ろ5。 $f_{5}$ と $f_{3}, f_{5}$ と $f_{7}$ のそれぞれの間の相関は前 2 者 の場合に比較すると若干低下することになり，さらに $f_{5}$ の位置 (時刻) から非常に離れた $f$ の值との間の相 関は不規則な波であるからほとんどゼ口になるであろろ ということが一応想像できる。すなわち不規則な波の性 格をとらえるのに上述の性質をくわしく調べることは一 つの有効な方法であると考党られよう。

い委時系列 $f_{1}, f_{2}, \cdots \cdots, f_{i}, \cdots \cdots, f_{N}$ 飞执いてま ず隣り同志の間の相関をみるためには

$$
R_{1}=\frac{1}{N-1} \sum_{i=1}^{N-1} f_{i} \cdot f_{i+1}
$$

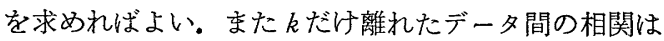

$$
R_{k}=\frac{1}{N-k} \sum_{i=1}^{N-k} f_{i} \cdot f_{i+k}
$$

となる.とくに $k=0$ の場合は

$$
R_{0}=\frac{1}{N} \sum_{i=1}^{N} f_{i} \cdot f_{i}=\frac{1}{N} \sum_{i=1}^{N} f_{i}^{2}
$$

であるから，前章でのべた分散の計算にほかならない。
こうして $k=0, \pm 1, \pm 2, \cdots \cdots$ 沉詨応して $R_{0}, R_{1}$, $R_{2}, \cdots \cdots$ が得られるが，横軸に $k \cdot \Delta t$ を，たて軸に $R$ をとるとたとえば第 22 図が得られる，定常時系列であ れば左右対象になるはずであるから普通は $k \geq 0$ の場合 のみを計算すればよい。こうして得られる関数 $R(\tau)$ を 自己相関関数と称する.ただし $\tau=k \cdot \Delta t$ すなわち $\tau$ は

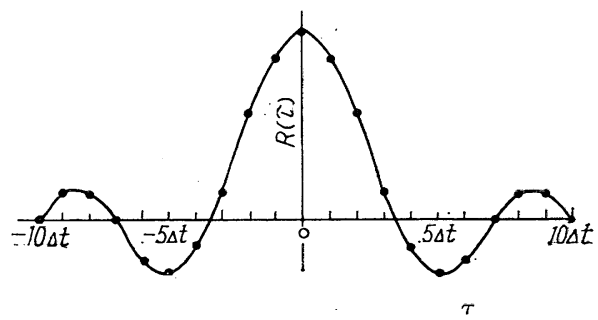

（第 22 図）自己相関関数の例

ずらし時間で， $R(\tau)$ は時間 $\tau$ だけ離れた值の間の相関 を示している.

第 20 図の場合のように連続な曲線 $f(t)$ に対して, 厳 密には自己相関関数は

$$
R(\tau)=\lim _{\mathcal{P} \rightarrow \infty} \frac{1}{2 T} \int_{-P}^{T} f(t) \cdot f(t+\tau) d t
$$

と定義されている。

自己相関関数の意義は以上のようであるが，特殊な場 合として波の波形が正弦波や矩形波のような場合の $R(\tau)$ を示すと第 23 図のごとくである.

いをたとえば第 24 図のように定常不規則な変動 $f_{1}(t)$
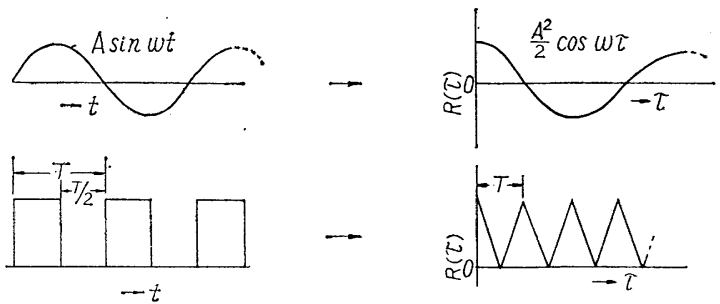

（第 23 図）特別な波形の自己相関関数
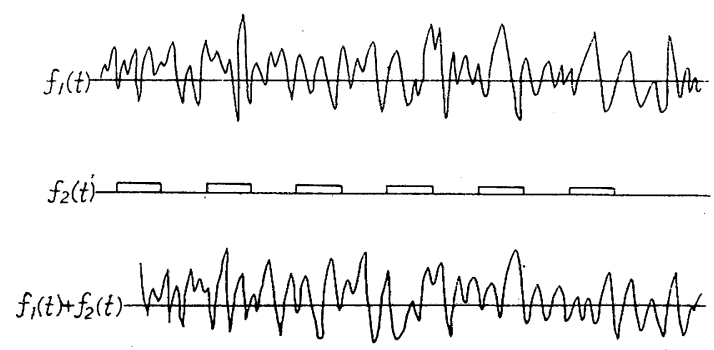

（第 24 図）不規則波と規則波の重量 
そ規則的な $f_{2}(t)$ が混じった和の変動 $f_{1}(t)+f_{2}(t)$ が あるとき, $f_{1}(t)+f_{2}(t)$ の波からは $f_{2}(t)$ の存在がわ からないとする。この場合 $R(\tau)$ を調べてみると

$$
\begin{aligned}
R(\tau) & =\lim _{T \rightarrow \infty} \frac{1}{2 T} \int_{-T}^{T}\left\{f_{1}(t)+f_{2}(t)\right\}\left\{f_{1}(t+\tau)\right. \\
& \left.+f_{2}(t+\tau)\right\} d t \quad \ldots \ldots \ldots \ldots \ldots \ldots \ldots \ldots \ldots \ldots \ldots \ldots \ldots \ldots \ldots \ldots \ldots \ldots
\end{aligned}
$$

すなわち

$$
\begin{aligned}
=\lim _{\mathcal{T} \rightarrow \infty} & \frac{1}{2 T} \int_{-\mathcal{T}}^{\mathcal{T}}\left\{f_{1}(t) \cdot f_{1}(t+\tau)+f_{2}(t) \cdot f_{2}(t+\tau)\right. \\
& \left.+f_{1}(t) f_{2}(t+\tau)+f_{2}(t) \cdot f_{1}(t+\tau)\right\} d t \cdots(59)
\end{aligned}
$$

となり積分記号内の第 3,4 項は $f_{1}(t)$ と $f_{2}(t)$ の相 互相関項であるが両者の間の連帯性がまったくないと し,この項が無視できるものとすると（59）式は

$$
\begin{aligned}
& R(\tau)=\lim _{\boldsymbol{T} \rightarrow \infty} \frac{1}{2 T} \int_{-\boldsymbol{T}}^{\boldsymbol{T}}\left\{f_{1}(t) \cdot f_{1}(t+\tau)\right. \\
& \left.+f_{2}(t) \cdot f_{2}(t+\tau)\right\} d t
\end{aligned}
$$

となる。すなわち $f_{1}(t)$ と $f_{2}(t)$ の各自己相関関数を $R_{1}(\tau), R_{2}(\tau)$ とすれば

$$
R(\tau)=R_{1}(\tau)+R_{2}(\tau)
$$

になる。いま $R_{1}(\tau)$ が第 25 図のようであるならば $R(\tau)$ は第 26 図のようになり $f_{2}(\tau)$ の存在が ただちに わかることになる。

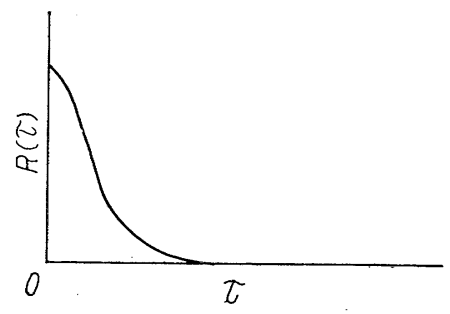

（第 25 図） $f_{1}(t)$ の自己相関関数

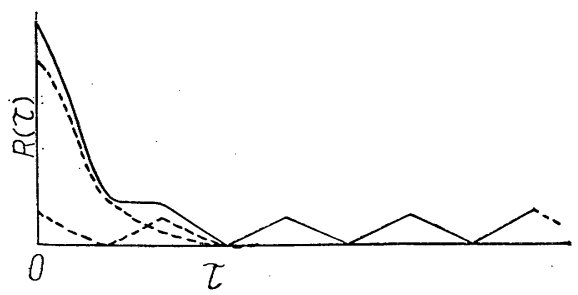

（第 26 図） $f_{1}(t)+f_{2}(t)$ の自己相関関数

いまむらの研究の場合を考学るとスライバあるいは糸 むらのむら曲線の波形は一般には不規則な形状をとり， このむらの波形からむらの性格を補足するためには以上 のべてきた解析手法も有力な手段の一つである。たとえ ばきわめて良好に紡績が行なわれ，人工的なむらがまっ
たくない場合は自己相関関数の形状はランダム スライ バのそれを示すであろうし，周期的な人工的要因のむら があるならば，たと緆 23 図に示したような形状が ランダム スライバの自己相関関数に第 26 図のように加 算されるであろろと思われる。また的なむらでる， いわゆるドラフトによって生じるドラフトむらの場合は ランダムスライバの自己相関関数が変形された形で現 われてくる。

こうした解析手法が実際の工程管理に具体的にどのよ うに生かすべきであるかは，こことは別の立場から論ず べきことであるので詳しくは触れないが，この問題はま た今後に発展が期待される新しいテーマでもある。なお 自己相関関数は最後でものべるようにスペクトル密度関 数の算出に利用されることが多い。

（3） 自己相関関数の計算法

自己相関関数 $R(\tau)$ を具体的に計算するにはかなりの 手数を必要とすることは定義式からるわかるであろうと 思5.

まず（57）式のように区間を無限大にとることが不可 能である.したがって有限区間の計算データから無限大 の場合の值を推定するしか仕方がない，乙かし有限区間 内の計算で推定精度を上げるためには区間長をかなりひ ろげる必要がある。したがって計算は機械的，または電子 的な計算機を用いるのがよいと思う。自己相関関数の計 算にはもちろん I BMのようなデイジタル電子計算機を 用いるのもよく，また相関計算專用のリレー式計算機も 市肘されている。しかしこのような方法による場合は， たと学ば系むらのような連続曲線から標本値を読み取ら ねばならない。もっともアナログーデイジタル変換器が あればこの必要はなくなる。一方，アナログ方式の電子 計算機による計算方法がある。たと皇録音用の磁気テ ープに信号をパルス化して読み取らせ，そのテープから 2 個の検出へッドを用いてヘッド間の距離をずらせて （すなわちてを変えて）それぞれのへッドで検出した 2 つの信号を掛算回路に入れるという方法などである.

しかしこのような電子計算機にたよらなくとも，もち ろん計算はできるわけでその方法をつぎにのべてみよ 5.

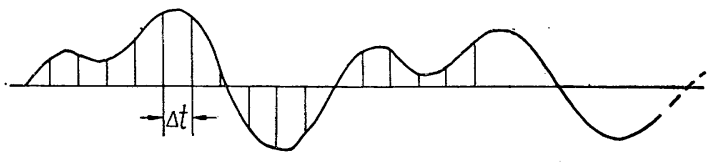

（第 27 図）サンプリング 
第 27 図のように，まず曲線を等間隔に分割してそれ ぞれの值をたとえば

$$
+3,+6,+7,+3,-2,
$$

のように読み取る。ここで分割の間隔は前章でのべた $\sigma^{2}$ の計算の場合と同様である.また計算区間 $T$ は検出 したい最大波長の約 10 倍以上にはとる必要がある.デ 一タ数 $N$ は

$$
N=\frac{T}{\Delta t}
$$

となるが糸むらの場合は $N$ は 500 以上にはなると思う。

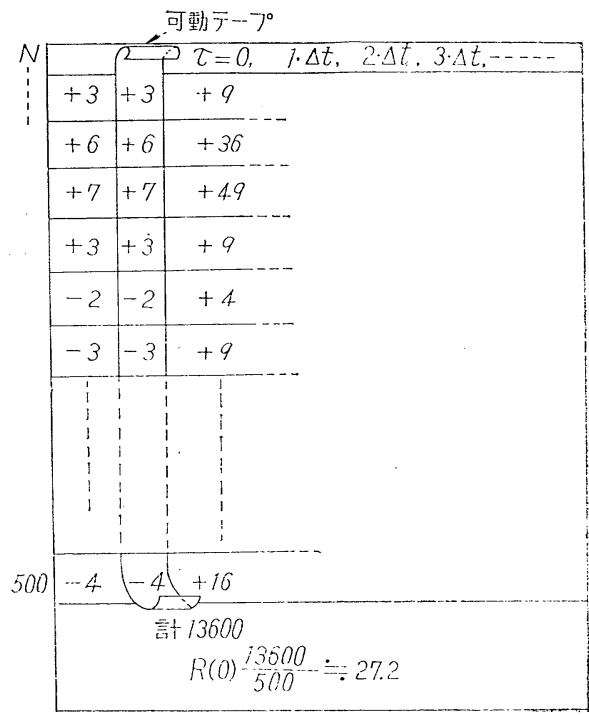

（第 28 図 ( a )） $\tau=0$ の場合の計算が 終ったところ

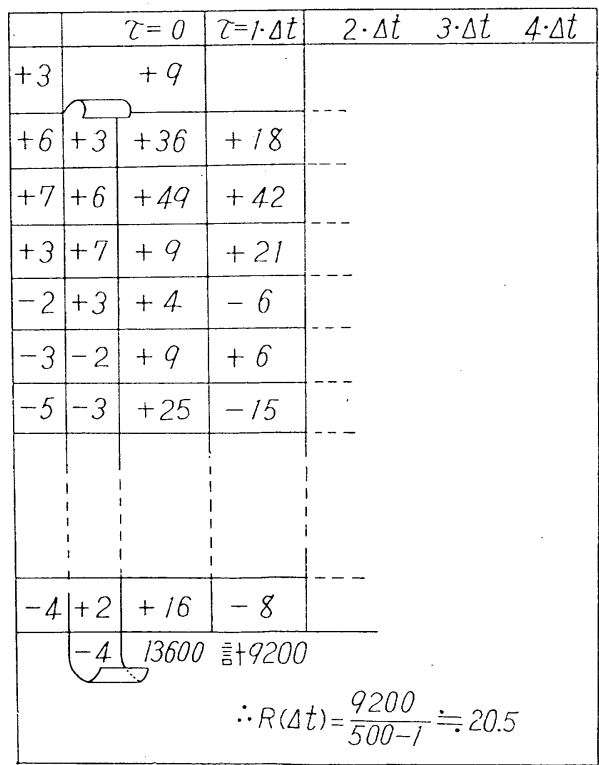

（第 28 図 $(\mathrm{b})) \quad \tau=1 \cdot \Delta t$ の場合の計算が 終ったところ
さて,このデータを第 28 図のように表の左端にたてに 記入し，同じものを可動テープにも記入する。そして可 動テープを 1 段ずつ下方へずらしながら掛算をしその和 を平均する。

このようにして $R(0), R(\Delta t), R(2 \Delta t), \cdots \cdots$ が求め られるから横軸に $\tau$ を，たて軸にRをとってプロットす ればよい。

なおたて軸を $R(\tau)$ のかわりに自己相関係数 $\rho(\tau)$ に とったものがコレログラムと称されているが，これは $R(\tau)$ からただちに導くことができる。

(4) スペクトル密度関数

自己相関関数によって不規則波形の性格がかなり明確 になってきたのであるが，たとえば第 2 章でものべたよ らに不規則波形が，ある特性の伝達要素を通過するとそ の不規則波形の性質がどのように変化するかという問題 に対してスペクトル密度関数が非常に役立ってくる。 た不規則波形が，どのような周波数成分からどのように 構成されているのかというきわめて具体的な性質を直接 示すことができる。

今回はこうしたフーリエ解析についての数学的な説明 や議論は省略するが，このスペクトル密度関数（これ を $Y(f)$ とする) は実は自己相関関数と密接な関係が ある。

$$
Y(f)=4 \int_{0}^{\infty} R(\tau) \cos 2 \pi f \tau d \tau
$$

の関係があり， $R(\tau)$ から誘導することができる。また 周波数 $f$ のかわりに波長 $p$ を変数にとって筆者らは $X(p)$ なるむらのスペクトラムを定義しているが，これ らの関数はむらに含まれている波長成分の強度を直接表 示するので，たとえば分散值 $\sigma^{2}$ だけではさらの性格が わからなかったのに対し， $X(p)$ はこの $\sigma^{2}$ を波長で分 解したスペクトルであるから，これによってさらの性格 も同時に明確にできるのである。

以上，時間の関係からまず基礎となる $1 ， 2 ， 3$ 節を 主にしてのべてきたが，最後の 4 節については別の機会 にあらためて詳しく論じたいと思っている。

本文の内容は昭和 37 年 2 月本会主催「むらの測定と 評価」講習会でのべたものである.

\section{文献}

1）野村民也 外；"アナログ電子計算機”，コロ于社 (東京) (1960)

2）ゴールドマン，関 英男訳；“情報理論”，近代科 学社 (東京) (1956)

3 ) 高橋安人; “自動制御計算法”, 共立出版 (東京) (1954)

4. ) 高橋安人；“自動制御理論”，岩波書店（東京） (1954)

5 ）藤野，川端；本誌，11，11（1958） 